Published in final edited form as:

Chem Res Toxicol. 2016 July 18; 29(7): 1151-1159. doi:10.1021/acs.chemrestox.6b00115.

\title{
Prodrugs Bioactivated to Quinones Target NF- $x$ B and Multiple Protein Networks: Identification of the Quinonome
}

\author{
Emily N. Pierce ${ }^{\dagger}$, Sujeewa C. Piyankarage $e^{\dagger, \ddagger}$, Tareisha Dunlap, Vladislav Litosh ${ }^{\S}$, Marton I. \\ Siklos", Yue-Ting Wang, and Gregory R. J. Thatcher ${ }^{\star}$ \\ Department of Medicinal Chemistry \& Pharmacognosy, College of Pharmacy, University of Illinois \\ at Chicago, 833 S. Wood Street, Chicago, Illinois 60612, United States
}

\section{Abstract}

Electrophilic reactive intermediates resulting from drug metabolism have been associated with toxicity and off-target effects and in some drug discovery programs trigger NO-GO decisions. Many botanicals and dietary supplements are replete with such reactive electrophiles, notably Michael acceptors, which have been demonstrated to elicit chemo-preventive mechanisms; and Michael acceptors are gaining regulatory approval as contemporary cancer therapeutics. Identifying protein targets of these electrophiles is central to understanding potential therapeutic benefit and toxicity risk. NO-donating NSAID prodrugs (NO-NSAIDs) have been the focus of extensive clinical and preclinical studies in inflammation and cancer chemoprevention and therapy: a subset exemplified by $p \mathrm{NO}-\mathrm{ASA}$, induces chemopreventive mechanisms following bioactivation to an electrophilic quinone methide (QM) Michael acceptor. Having previously shown that these NO-independent, QM-donors activated Nrf2 via covalent modification of Keap-1, we demonstrate that components of canonical NF- $x$ B signaling are also targets, leading to the inhibition of NF- $x$ B signaling. Combining bio-orthogonal probes of QM-donor ASA prodrugs with mass spectrometric proteomics and pathway analysis, we proceeded to characterize the quinonome: the protein cellular targets of QM-modification by $p$ NO-ASA and its ASA pro-drug congeners. Further comparison was made using a biorthogonal probe of the "bare-bones", Michael acceptor, and clinical anti-inflammatory agent, dimethyl fumarate, which we have shown to inhibit NF- $x$ B signaling. Identified quinonome pathways include post-translational protein folding, celldeath regulation, protein transport, and glycolysis; and identified proteins included multiple heat shock elements, the latter functionally confirmed by demonstrating activation of heat shock response.

\footnotetext{
*Corresponding Author. thatcher@uic.edu.

†Present Addresses

S.C.P.: Centers of Disease Control and Prevention, 1600 Clifton Road, Atlanta, GA 30329-4027.

\$V.L.: University of Cincinnati, Department of Medicinal Chemistry, 7148 Edwards One, Cincinnati, OH 45221-0037.

"M.I.S.: University of California San Francisco, Department of Cellular and Molecular Pharmacology, 600 16th Street, San Francisco, CA 94158.

$\dagger^{\dagger}$ E.N.P. and S.C.P. contributed equally to this work.

ASSOCIATED CONTENT

Supporting Information

The Supporting Information is available free of charge on the ACS Publications website at DOI: 10.1021/acs.chemrestox.6b00115.
}

Figures of QM modification of IKK $\beta$, p65, and $\beta$-catenin by WB, and SDS-PAGE gel for in-gel trypsin digestion of QM modified proteins; table of identified QM modified proteins from LC-MS/MS analysis (PDF)

The authors declare no competing financial interest. 


\section{Graphical abstract}

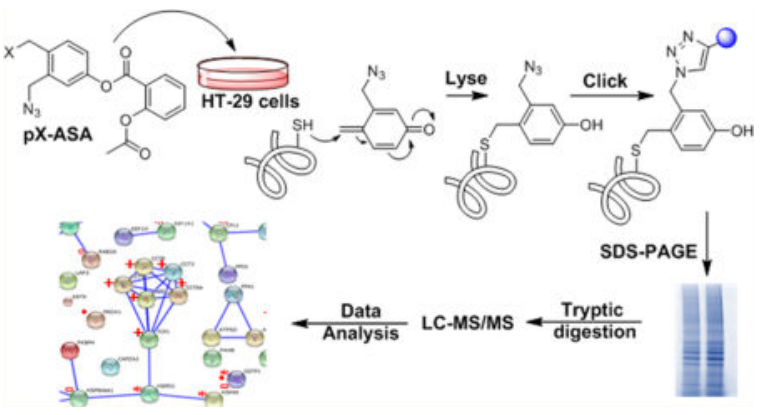

\section{INTRODUCTION}

In drug discovery, the pursuit of electrophilic drugs is generally avoided due to concerns of potential toxicity caused by off-target reactivity via covalent modification of multiple proteins. The bioactivation of small molecules resulting in the production of electrophilic metabolites is often considered a risk factor in drug development, leading to the termination of therapeutic programs. However, there are several examples of FDA-approved drugs that contain electrophilic groups and several that function directly through covalent modification of their protein targets. ${ }^{1,2} \mathrm{~A}$ recent, and perhaps surprising example, is the bare-bones Michael acceptor, dimethyl fumarate (Tecfidera), an anti-inflammatory drug approved in 2013 for the treatment of multiple sclerosis (MS), which we have recently shown to inhibit tumorigenesis by inhibition of NF- $\kappa$ B signaling in triple-negative breast cancer (TNBC) cell lines. ${ }^{3-6}$

The potential use of nonsteroidal anti-inflammatory drugs (NSAIDs), particularly aspirin (acetylsalicylic acid, ASA), in cancer chemoprevention is supported by a large body of literature and epidemiological studies but contraindicated by side effects, including gastrotoxicity. ${ }^{7-9}$ Hybrid NO-donating NSAIDs (NO-NSAIDs), originally conceived to overcome NSAID gastrotoxicity, have been the subject of well over 100 publications. ${ }^{10,11} \mathrm{~A}$ particularly promising spectrum of cancer chemopreventive and chemotherapeutic activity was reported in cell cultures and in animal models for the hydroxybenzyl-linked NO-ASA hybrids, including NCX-4040 ( $p$ NO-ASA). ${ }^{12,13}$ We demonstrated that this spectrum of activity could be replicated in cell cultures by congeners ( $p \mathrm{X}-\mathrm{ASA}$ ) not containing an NOdonating group and was the result of bioactivation to a Michael acceptor quinone methide (QM). ${ }^{10,14-16}$ Alternative ASA and NSAID hybrid molecules, devoid of any putative NOdonating capacity, have been developed and validated in animal models: for example, phospho-aspirins have been reported to have an improved gastrointestinal toxicity profile relative to ASA and have been studied in cancer cell lines and xenografts. ${ }^{17-19} \mathrm{~A}$ recent publication on the quinone-donor aspirin, $p \mathrm{NO}-\mathrm{ASA}$, reported antiproliferative effects in TNBC xenografts, proposed to be mediated through inhibition of the NF-kB pathway and induction of ROS. ${ }^{20}$ Another study in multiple myeloma cells reported $p$ NO-ASA to increase the expression of cell surface proteins leading to an increased susceptibility of the multiple myeloma cells to NK cell-mediated killing. ${ }^{21}$ We have recently shown that quinone-donor aspirins ( $p \mathrm{X}-\mathrm{ASA}$ ) selectively inhibited growth of cells with cancer stem cell 
(CSC) character $\left(\mathrm{CD} 44^{+} \mathrm{CD} 24^{-}\right.$immunophenotype) in mammospheres and produced concentration dependent inhibition of tumorigenesis in a mouse model. ${ }^{22}$

Given continued reports of the therapeutic potential of $p \mathrm{X}$-ASA drugs and the importance of quinone reactive intermediates in drug metabolism, the quinonome that defines the protein targets of these electrophiles needs to be identified. We have shown that $p$ NO-ASA and $p \mathrm{X}$ ASA covalently modify the Cys residues of Keap1, leading to activation of Nrf2 and induction of cytoprotective and detoxifying enzymes, considered important in chemoprevention. ${ }^{16,23}$ Similarly, the QM from $p$ NO-ASA and $p \mathrm{X}$-ASA is likely to react with a variety of other proteins, via covalent protein modification, which may play crucial physiological roles including in cell viability and apoptosis. This study is focused on identifying the quinonome via a proteomic pathway analysis. Comparison is also made with the clinical Michael acceptor, DMF.

\section{EXPERIMENTAL PROCEDURES}

\section{Chemicals and Reagents}

All chemicals and reagents were purchased from Sigma-Aldrich (St. Louis, MO) unless stated otherwise. $p$ NO-ASA was purchased from Cayman Chemicals (Ann Arbor, MI) or synthesized with other $p \mathrm{X}$-ASA congeners as described in the literature. Alkyne-DMF was synthesized as described. ${ }^{25}$ The synthesis of azido- $p$ NO-ASA, azido- $p$ Br-ASA, and ethynylbiotin are described below. ${ }^{14,24}$

\section{Synthesis of Azido-pNO-ASA, Azido-pBr-ASA, Ethynyl-Biotin, and Alkyne-DMF}

3-Azidomethyl-4-(2-acetoxybenzoyl)benzyl Bromide)-To a vigorously stirred solution of triphenylphosphine $(0.409 \mathrm{~g}, 1.56 \mathrm{mmol})$ in anhydrous DMF $(2 \mathrm{~mL})$ under argon atmosphere, bromine $(82 \mu \mathrm{L}, 1.60 \mathrm{mmol})$ was added at $0{ }^{\circ} \mathrm{C}$. The reaction mixture was stirred for $30 \mathrm{~min}$ while gradually warming up to room temperature. The reaction mixture was then immersed in an ice-water bath, and a solution of 3-azidomethyl-4-(2acetoxybenzoyl)-benzyl alcohol $(0.162 \mathrm{~g}, 0.459 \mathrm{mmol})$ in anhydrous DMF $(1 \mathrm{~mL})$ was added. The mixture was stirred at $60{ }^{\circ} \mathrm{C}$ under argon for $16 \mathrm{~h}$, then cooled down to room temperature and concentrated under reduced pressure. The residue was purified by column chromatography $\left(\mathrm{SiO}_{2}\right.$, hexane-ethyl acetate 10:1) to afford $134 \mathrm{mg}(72 \%)$ of product.

3-Azidomethyl-4-(2-acetoxybenzoyl)benzyl nitrate-To a solution of 3azidomethyl-4-(2-acetoxybenzoyl)benzyl chloride $(68 \mathrm{mg}, 0.189 \mathrm{mmol})$ in anhydrous acetonitrile $(3 \mathrm{~mL})$, silver nitrate $(71 \mathrm{mg}, 0.416 \mathrm{mmol})$ was added. The mixture was stirred at $45{ }^{\circ} \mathrm{C}$ in the dark under argon for $22 \mathrm{~h}$. The solvent was evaporated under reduced pressure, and the residue was purified by column chromatography $\left(\mathrm{SiO}_{2}\right.$, hexane-ethyl acetate $8: 1)$ to afford $53 \mathrm{mg}(73 \%)$ of product.

(3aS),(4S),(6aR)-Hexahydro-2-oxo-N-2-propyn-1-yl-1H-thieno-[3,4d]imidazole-4-pentanamide-To a vigorously stirred solution of EDCI (1.02 g, 5.32 $\mathrm{mmol})$ in anhydrous DMF $(10 \mathrm{~mL})$ under argon atmosphere D-biotin $(0.59 \mathrm{~g}, 2.42 \mathrm{mmol})$ and DIPEA $(1.14 \mathrm{~mL}, 6.53 \mathrm{mmol})$ were added at $0{ }^{\circ} \mathrm{C}$. The mixture was stirred for $15 \mathrm{~min}$ 
followed by the addition of propargylamine $(0.15 \mathrm{~g}, 2.67 \mathrm{mmol})$ in anhydrous DMF $(5 \mathrm{~mL})$. The cond bath was removed, and the reaction mixture was stirred for $48 \mathrm{~h}$ while gradually warming up to room temperature. The solvent was removed under reduced pressure, and the residue was purified by column chromatography $\left(\mathrm{SiO}_{2}\right.$, dichloromethane-methanol eluting from 1:0 to $25: 1)$ to afford $0.42 \mathrm{~g}(61 \%)$ of $(3 \mathrm{a} S),(4 S),(6 \mathrm{a} R)$-hexahydro-2-oxo- $N-2$ propyn-1-yl-1 $H$-thieno[3,4- $d$ ] imidazole-4-pentanamide.

\section{Cell Culture}

HT-29 human colon cancer cells were obtained from American Type Culture Collection and maintained in McCoy's 5A medium supplemented with $10 \%$ fetal bovine serum and $1 \%$ penicillin-streptomycin.

\section{HSE-Luciferase Reporter Assay}

HT-29 cells were plated in 12-well plates and transfected with HSE-luciferase reporter plasmid $(1 \mu \mathrm{g})$ and pRL-TK (400 ng) in each well using Lipofectamine 2000 reagent (Invitrogen, Carlsbad, CA). Cells were treated with the compound for $24 \mathrm{~h}$, washed with PBS, and lysed with passive lysis buffer. Lysates were assayed for luciferase activity with Promega Dual-Luciferase Reporter Assay System (Madison, WI).

\section{NF- $x$ B-Luciferase Reporter Assay}

HT-29 cells were plated in 12-well plates and transfected with the NF- $x$ B pTAL-luciferase reporter plasmid $(1 \mu \mathrm{g})$ and pRL-TK luciferase reporter vector (400 $\mathrm{ng})$ in each well using Lipofectamine 2000 reagent (Invitrogen, Carlsbad, CA). Cells were pretreated with the ASA compounds for $2 \mathrm{~h}$ followed by $4 \mathrm{~h}$ treatment with TNF- $a(10 \mathrm{ng} / \mathrm{mL})$, and the cells were lysed with passive lysis buffer. Lysates were assayed for luciferase activity with Promega Dual-Luciferase Reporter Assay System (Madison, WI).

\section{NF- $x$ B Translocation}

HT-29 cells plated in eight-well Nunc chamber slides were treated with the ASA compounds $(10,25 \mu \mathrm{M})$ or with BAY 11-7082 $(1 \mu \mathrm{M})$ for $1 \mathrm{~h}$ and TNF- $a$ for an additional $30 \mathrm{~min}$ followed by fixing with $10 \%$ formalin solution. Cells were washed with PBS, and $0.5 \%$ Triton X-100 solution was added for $10 \mathrm{~min}$. The cells were washed with PBS, blocked with $1 \%$ BSA for $1 \mathrm{~h}$, and incubated overnight with rabbit polyclonal anti-NF- $\kappa \mathrm{B}$ (p65) antibody (Cell Signaling). Cells were then incubated with fluorescein-conjugated antirabbit IgG secondary antibody for $1 \mathrm{~h}$ (Jackson ImmunoResearch Laboratories, Inc., West Grove, PA), and VECTASHIELD mounting medium with DAPI (Vector Laboratories, Burlingame, CA) was added to the cells to detect nuclear staining. Imaging was performed with a Zeiss LSM 510 laser-scanning confocal microscope. The fluorescence signal from NF- $x$ B was monitored with a $488 \mathrm{~nm}$ argon/krypton laser and a $530 \mathrm{~nm}$ band-pass filter. The DAPI nuclear staining signal was monitored with a $345 \mathrm{~nm}$ UV laser and $420 \mathrm{~nm}$ band-pass filter. Images were analyzed using the analysis tool provided in the Zeiss biophysical software package and ImageJ. 


\section{HT-29 Cell Lysate Sample Preparation}

The HT-29 cells were treated with the QM-releasing azido- $p$ NO-ASA or azido- $p \mathrm{Br}$-ASA $(100 \mu \mathrm{M})$ compound at $30^{\circ} \mathrm{C}$ for $30 \mathrm{~min}$, and after the treatment, the media were removed, and cells washed with PBS were collected in $350 \mu \mathrm{L}$ of fresh lysis buffer (Cell Signaling Technology) containing $1 \mathrm{mM}$ PSMF. Following $10 \mathrm{~min}$ of incubation on ice, the cells were sonicated, the resulting mixture was centrifuged at $4{ }^{\circ} \mathrm{C}$ at $14,000 \mathrm{rpm}$ for $10 \mathrm{~min}$, and the supernatant was collected for further experiments. Protein concentration of the collected lysate was measured using a Pierce BCA protein assay kit (Thermo Scientific) following the standard procedure. The supernatant was reacted with $5 \mathrm{mM}$ sodium ascorbate, $1 \mathrm{mM}$ $\mathrm{CuSO}_{4}$, and $200 \mu \mathrm{M}$ ethynyl-biotin for $1 \mathrm{~h}$ at $37^{\circ} \mathrm{C}$ to click biotin to the azide-tagged QMmodified proteins. The lysate was filtered through $10 \mathrm{kDa}$ Amicon filters to remove the excess reagents followed by reducing with TCEP $(50 \mathrm{mM})$ at $60{ }^{\circ} \mathrm{C}$ for $10 \mathrm{~min}$ and reacting with $5 \mathrm{mM}$ NEM at $25^{\circ} \mathrm{C}$ for $1 \mathrm{~h}$ to label reduced and unreacted Cys thiols. The QMmodified proteins were separated using the streptavidin-coated magnetic beads (Invitrogen). The QM-modified and unmodified fractions were subjected to SDS-PAGE gel electrophoresis, and following Coomassie brilliant blue staining, protein bands were then excised, destained, digested using the Pierce in-gel trypsin digestion kit (Thermo Scientific) and stored at $-20{ }^{\circ} \mathrm{C}$ until further analyses.

\section{Western Blot and In-gel Fluorescence Visualization of QM and DMF Modified Proteins}

Western blot experiments were carried out with the clicked and processed lysate samples for the visual comparisons of the QM-modified proteins using the HRP-linked antibiotin antibody (Cell Signaling Technology). In-gel fluorescence visualization was used to confirm the QM and DMF-modification of specific proteins recombinant NF- $\kappa \mathrm{B}$, (Enzo Life Sciences) IKK $\beta$, and $\beta$-Catenin (Sigma-Aldrich). $0.1 \mu \mathrm{g} / \mu \mathrm{L}$ of each recombinant protein was incubated in $0.1 \mathrm{M}$ phosphate buffer $\mathrm{pH} 7.4$ with $10 \mu \mathrm{M}$ azido $p$ NO-ASA, azido- $p$ Br-ASA, or alkyne-DMF at $37^{\circ} \mathrm{C}$ for $0.5 \mathrm{~h}$. Samples with pX-ASA were carried out in the presence of $30 \mu \mathrm{g} / \mathrm{mL}$ porcine liver esterase. Click chemistry with azido- or alkynylcarboxyrhodamine 110 (Click Chemistry Tools) was then used prior to SDS-PAGE gel electrophoresis. The gel was then visualized by in-gel fluorescence using the GE Typhoon Trio imager to detect IKK $\beta$, NF- $\alpha \mathrm{B}$, and $\beta$-catenin modification. Total protein modification by azido- $p$ NO-ASA, azido- $p$ Br-ASA, or alkyne-DMF in PC12 cell lysates $(1 \mu \mathrm{g} / \mu \mathrm{L})$ was performed using the same sample preparation conditions and visualization methods.

\section{Reaction of Recombinant IKK- $\beta$ with $p$ NO-ASA or $p \mathrm{Br}-\mathrm{ASA}$}

For the analysis of alkylation of IKK- $\beta$ Cys residues, $15 \mu \mathrm{M}$ IKK- $\beta$ (Sigma-Aldrich, Saint Louis, MO) was incubated with $30 \mu \mathrm{M}$ substrate ( $p \mathrm{NO}-\mathrm{ASA} / p \mathrm{Br}-\mathrm{ASA}$ ) in the presence of $30 \mu \mathrm{g} / \mathrm{mL}$ porcine liver esterase in $40 \mathrm{mM}$ phosphate buffer at $\mathrm{pH} 7.4$ for $30 \mathrm{~min}$ at $37^{\circ} \mathrm{C}$. The unreacted thiols were then blocked by incubating the protein samples with $20 \mathrm{mM}$ NEM in the presence of $5 \% \mathrm{SDS}$ for $30 \mathrm{~min}$ at $55^{\circ} \mathrm{C}$ with vortexing at every $5 \mathrm{~min}$ intervals. Prepared samples were run on SDS gel, and the separated protein bands were stained with Coomassie brilliant blue. Finally, bands containing the IKK- $\beta$ region, determined by visual inspection, were excised, destained, and digested using trypsin enzyme according to the manufacturer's (Thermo Pierce, IL) instructions. 


\section{Mass Spectrometric Analysis of Digested Proteins}

The protein digests with $1 \%$ formic acid were analyzed using the hybrid LTQ-FT linear ion trap mass spectrometer (LTQ FT, Thermo Electron Corp., Bremen, Germany) equipped with a nanospray ESI source and nano-HPLC with autosampler (Dionex, Sunnyvale, CA). The trapping cartridge and the nanocolumn used for separation were Zorbax 300 SB-C18 (5 $\times$ $0.3 \mathrm{~mm}, 5 \mu \mathrm{m}$, Agilent Technologies) and Zorbax $300 \mathrm{SB}-\mathrm{C} 18$ (150 mm $\times 75 \mu \mathrm{m}, 3.5 \mu \mathrm{m}$, Agilent Technologies), respectively. The separations were carried out at $250 \mathrm{~nL} / \mathrm{min}$ flow rate at a gradient with the mobile phase containing $95 / 5(\mathrm{v} / \mathrm{v})$ water/acetonitrile and $0.1 \%$ formic acid. The raw MS/MS data files acquired by an LTQ-FT-ICR mass spectrometer were converted to MGF files and were searched by Mascot (Matrix Science, London, UK; version 2.2.07 http://www.matrixscience.com) against the SwissProt_57.15 protein database (selected for Homo sapiens, unknown version, 20266 entries) with the appropriate (NEM and QM) variable modifications. Mascot was searched with a fragment ion mass tolerance of $0.60 \mathrm{Da}$ and a parent ion tolerance of $10.0 \mathrm{ppm}$. For protein identification (ID), Scaffold (version Scaffold_4.4.7, Proteome Software Inc., Portland, OR) was used to validate MS/MS based peptide and protein identifications. Peptide identifications were accepted if they could be established at greater than $95.0 \%$ probability by the Peptide Prophet algorithm. ${ }^{26}$ Protein identifications were accepted if they could be established at greater than $95.0 \%$ probability and contained at least 2 identified peptides. Protein probabilities were assigned by the Protein Prophet algorithm. ${ }^{27}$ The peak areas of the NEM and QM modified peptide fragments were quantified to determine the percentage modifications.

\section{Gene Ontology, Protein Network, and Pathway Analyses}

For gene ontology (GO) interpretations, UniProt IDs of the identified proteins submitted to GORetriever were categorized using CateGOrizer. ${ }^{28}$ Physical and functional protein interconnectivities were established using the STRING, version 9.1 database (http://stringdb.org/). ${ }^{29,30}$ Associated pathways of the identified proteins were analyzed using the MetaCore software (Thomson reuters).

\section{RESULTS AND DISCUSSION}

\section{Nrf2 Pathway Activation and NF- $x$ B Pathway Inhibition}

We have previously reported covalent modification of Keap1 resulting from treatment of HepG2 cells with QM-donors, $p$ NO-ASA, and $p$ Br-ASA, leading to Nrf2 signal transduction, ARE activation, and NQO1 upregulation. ${ }^{23}$ The reported biological activity of $p$ NO-ASA has also been linked to NF- $\kappa$ B pathway inhibition, including in colon cancer cell lines; therefore covalent modification of proteins in the NF- $\kappa$ B pathway is a likely mechanism for $p \mathrm{NO}-\mathrm{ASA}$ and for other QM-donor compounds such as $p \mathrm{Br}-\mathrm{ASA}$. The QMdonor ASA hybrids were studied in HT-29 colon cancer cells transiently transfected with NF- $\kappa$ B-luciferase. Pretreatment of these cells with $p \mathrm{Br}$-ASA or $p$ NO-ASA $(1,10 \mu \mathrm{M})$ resulted in concentration dependent inhibition of NF- $\kappa$ B activation induced by treatment with TNFa $(10 \mathrm{ng} / \mathrm{mL})$ (Figure $1 \mathrm{~A})$.

Nuclear translocation of NF- $\kappa$ B (p65) was also studied by confocal fluorescence microscopy in HT-29 cells treated with $p$ NO-ASA or $p$ Br-ASA $(10,25 \mu \mathrm{M})$, using DAPI nuclear stain 
and NF- $\kappa$ B immunocytochemistry (Figure 1B). The vehicle-treated cells showed the expected localization of NF- $x$ B in the cytoplasm, while TNF $a(10 \mathrm{ng} / \mathrm{mL})$ treatment induced the expected translocation of NF- $\kappa$ B to the nucleus. Pretreatment of HT-29 cells with BAY 11-7082 $(1 \mu \mathrm{M})$, a compound known selectively and irreversibly to inhibit NF- $\kappa$ B activation, provided a positive control. ${ }^{31}$ We observed that pretreatment with $p$ NO-ASA or $p \mathrm{Br}$-ASA $(10$ and $25 \mu \mathrm{M})$ resulted in the inhibition of TNF $a$-induced NF- $\kappa \mathrm{B}$ nuclear translocation.

\section{Identifying and Measuring $p N O-A S A$ and $p X-A S A$ Protein Targets: NF- $x$ B Signaling}

Inhibition of NF- $\kappa$ B signaling by $p \mathrm{NO}-\mathrm{ASA}$ and $p \mathrm{Br}$-ASA likely involves covalent modification of key signaling proteins by the QM released on bioactivation. NF- $\kappa \mathrm{B}$ is sequestered in the cytoplasm by IkB inhibitory proteins that are phosphorylated by IKK- $a$ and IKK- $\beta$ leading to IkB degradation and subsequent NF- $\kappa$ B translocation and activation. 32,33 Covalent modification or oxidation of Cys residues of IKK- $\beta$ has been shown to regulate NF- $\kappa$ B nuclear translocation. ${ }^{34-36}$ Covalent modification of purified IKK- $\beta$ by the QM generated from $p$ NO-ASA was studied using bioactivation by porcine liver esterase (PLE). We identified eight QM-modified IKK- $\beta$ Cys residues after incubation with $p$ NOASA $(25 \mu \mathrm{M})$ (Table 1). Quantitation of QM modification was achieved using NEM to alkylate and block free, unmodified Cys residues. Several QM modified Cys residues were identified, and the extent of modification ranged from $18 \%$ to $95 \%$. Some of the QM modified Cys residues, including Cys12, Cys46, Cys59, and Cys299, are located within the kinase domain of IKK- $\beta$. These results are consistent with the observed inhibition of NF- $x$ B nuclear translocation (Figure 1). ${ }^{35}$ The absence of QM-modification observed for Cys residues, Cys114, Cys115, Cys464, Cys618, and Cys662, is accounted for by the presence of intra- or intermolecular disulfide bonds. Thus, covalent QM-modification of IKK- $\beta$ by ASA prodrugs upon bioactivation contributes to inhibition of NF- $\kappa \mathrm{B}$ activation and nuclear translocation.

To determine if other proteins in the canonical NF- $\kappa$ B pathway were also targets for QMmodification, we synthesized biorthogonal probes: analogues of $p \mathrm{NO}-\mathrm{ASA}$ and $p \mathrm{Br}-\mathrm{ASA}$ containing ligating azido tags (Scheme 1) ${ }^{14,15,37}$ Esterase-mediated bioactivation of azido$p \mathrm{NO}-\mathrm{ASA}$ and azido- $p \mathrm{Br}$-ASA liberates the electrophilic QM, tagged with an azido group $\left(\mathrm{N}_{3} \mathrm{QM}\right)$, which allows "clicking" to alkynyl-probes linked to biotin or to a fluorophore. Incubation of NF- $\alpha$ B signaling proteins with PLE and either azido- $p$ NO-ASA or azido- $p \mathrm{Br}-$ ASA allows for the visualization of $\mathrm{N}_{3} \mathrm{QM}$-modified proteins by in-gel fluorescence. Bioactivation of ASA prodrugs $(10 \mu \mathrm{M})$ led to covalent modification of IKK $\beta$, p65/RELA, and $\beta$-catenin (Figure 2). Similar observations were made using biotin tagging and Western blotting (Figure S1). Therefore, our biorthogonal probe approach confirmed the QM modification of IKK $\beta$ and indicated that $\mathrm{p} 65$ and $\beta$-catenin modification can also contribute to NF- $\kappa$ B pathway inhibition by $p$ NO-ASA and other QM-donor ASA hybrid drugs.

\section{Identifying the Quinonome: QM Targets from ASA Prodrug Bioactivation}

The azido-probes permit proteomic identification of the quinonome: the protein targets of the simple QM released upon bioactivation of ASA prodrugs by cellular nonspecific esterase activity. After treatment of HT-29 cells with azido-probes, the cells were lysed, and the cell 
lysates were treated with alkynyl-linked biotin to ligate $\mathrm{N}_{3} \mathrm{QM}$-modified proteins, followed by filtering to remove the excess reagents and application to streptavidin-coated magnetic beads to separate the QM-modified proteins from the unmodified proteins. Coomassie blue staining of modified and unmodified protein eluates is useful to estimate the degree and pattern of covalent modification. Distinct and similar bands of QM-modified proteins were observed for both ASA prodrugs against a background of extensive modifications to the proteome; and in both cases, the amount of modified protein was substantially lower than total protein (Figure 3A).

Western blotting of the gels obtained from treated cell lysates, imaged by antibiotin-HRP, showed strong similarities between the two ASA prodrug treatments. Competition experiments were conducted using pretreatment of intact HT-29 cells with the $p$ NO-ASA or $p \mathrm{Br}$-ASA prodrugs, followed by incubation with the alternate azido-probes; however, little if any attenuation of protein band intensity was observed (Figure 3B), compatible with the observations using Coomassie blue staining showing that the larger proportion of the proteome remains unmodified. That is, the partial covalent modification of protein thiols by QM does not block the partial modification of the same thiols by $\mathrm{N}_{3} \mathrm{QM}$. The $\mathrm{QM}$ quinonome therefore contains a large number of proteins that undergo partial covalent modification.

\section{Proteomics Analysis of the Quinonome in HT-29 Cells}

The lysates of HT-29 cell treated with azido- $p$ NO-ASA and azido- $p$ Br-ASA contain QMmodified as well as unmodified proteins. The QM-modified proteins were isolated using streptavidin-coated magnetic beads. These proteins were run on SDS-PAGE and the excised protein bands (20-120 kDa; Figure S2) subjected to in-gel tryptic digestion followed by analysis using LC-MS/MS. The MS and MS/MS data were analyzed using Mascot and searched against the SwissProt_57.15 database for Homo sapiens; the protein identification results were subsequently validated by Scaffold. As a result, 356 proteins with $0.1 \%$ Prophet FDR were identified for azido- $p \mathrm{NO}-\mathrm{ASA}$ and azido- $p \mathrm{Br}-\mathrm{ASA}$ treated cells, representing a sampling of the quinonome (see Supporting Information Table 1 for the full tabulation).

For interpretation of the gene ontology (GO) of the identified targets, protein IDs were submitted to GORetriever and categorized in GOslim using CateGOrizer. ${ }^{28} \mathrm{GO}$ annotation based on molecular functions shows involvement of $90 \%$ of the identified QM-modified proteins with binding, catalytic, and enzyme regulator activities while categorization of modified proteins by biological process indicates cellular, biological regulation, metabolic, and response to stimulus processes as the main contributors (Figure 4A,B). Gene ontology of target proteins shows the interconnections among proteins and their significance in cellular mechanisms and functions. Such a protein interconnectivity map was established using the STRING database of known and predicted protein-protein interactions including direct and indirect functional associations (Figure 4C). ${ }^{29,30}$ The SRTING analysis identified 75 interactions among 52 proteins that formed highly interconnected protein networks at a 90\% confidence level. The networks contain clusters enriched with proteins involved in the vital physiological roles: post-translational protein folding, cell-death regulation, protein transport, and glycolysis. 
Proteins that are known to be part of oncogene and MAPK signaling pathways were components of the quinonome. Heat shock proteins (HSPs) are key targets of quinone modification: HSP70 proteins such as HSPA5, HSPA6, HSPA8, HSPA1A, HSPA1B, HSPA1L, and HSP72A1B; and three HSP90 proteins HSP90AA1, HSP90B1, and HSP90AB1 were targets for the QM resulting from ASA prodrug bioactivation. Protein disulfide isomers (PDI), HSP60, and annexin A2 are among the chaperones targeted by QM, and some of these targets are part of the formed STRING networks (Figure 4C). In addition, to tracing the canonical pathways associated with the QM-modified protein targets, identified proteins were analyzed using the MetaCore software, yielding 20 pathways meeting statistical significance $(P<0.05)$ (Figure 5). HSP90, HSP70, calnexin, and PDIs are the common protein targets among the majority of the recognized pathways. While this type of proteomic analysis provides important information regarding the proteins included in the quinonome, as well as signaling pathways and cellular processes that may be affected by quinone modification, further investigation into how these observed modifications alter cellular function is required.

\section{QM Modification of Heat Shock Proteins}

Given the range of HSPs in the quinonome, it was anticipated that quinone donors would activate the heat shock response in HT-29 cells. This was confirmed by comparison of $p$ NOASA with the non-QM generating congener, $m \mathrm{NO}-\mathrm{ASA}$, and the endogenous heat shock response element activator 4-hydroxynonenal (4-HNE) (Figure 6). HSPs delay the apoptotic response, and the major HSPs related to the apoptotic pathways are HSP90, HSP70, and HSP60, with HSP90 in particular considered as a viable drug target. ${ }^{38-40}$ Interaction of HSP90 with RIP and Akt pathways has been reported to promote NF- $x$ B mediated inhibition of apoptosis and regulation of the NF- $\kappa$ B-controlling IKK complex by HSP70 and HSP90. ${ }^{38,41}$ HSP90 and HSP70 were identified in the quinonome, and their role in cellular regulation of NF- $\kappa$ B indicates that this QM modification may also contribute indirectly to the observed inhibition of NF- $\kappa$ B activation and nuclear translocation (Figure 1). However, more focused mechanistic studies are required to determine the extent to which these modifications contribute to the inhibition of NF- $x$ B nuclear translocation.

\section{Comparison with the Clinical Electrophile DMF (Tefucedra)}

DMF is a very simple Michael acceptor electrophile, whereas bardoxolone (CDDO-Me) incorporates the $a, \beta$-unsaturated electrophile into a triterpenoid. Bardoxolone has been in clinical trials for cancer therapy and kidney disease, and although commonly classed as an Nrf2 activator, a proteomic pathway analysis using a biotinylated probe indicated the modification of multiple proteins. ${ }^{42}$ Some of the molecular functions and biological process annotated in the CDDO-Mealkyl-biotin probe analysis are also targeted by our quinone donors, including enzymatic regulator activity, metabolic processes, catalytic activity, and multicellular organismal development. A gene array analysis, comparing CDDO with DMF, confirmed common activation of Nrf2 pathway genes and Nrf2-independent genes. ${ }^{43}$

DMF is an FDA-approved immunosuppressant used clinically to treat multiple sclerosis. Therefore, it was interesting to compare DMF with the QM donors, $p \mathrm{NO}-\mathrm{ASA}$, and $p \mathrm{Br}$ ASA. A biorthogonal probe of DMF was prepared for incubation with HT-29 cells and for 
incubation with the recombinant proteins, $\beta$-catenin, IKK $\beta$, and p65. A similar click chemistry and in-gel fluorescence approach was used to visualize protein modification. Similar to the quinone donor prodrugs, we observed the modification of IKK $\beta$ and p65 by the alkyne-DMF probe; however, no detectible modification of $\beta$-catenin was observed (Figure 7A). In a cellular context, comparison of QM-donors with DMF showed that the extent of protein modification by DMF was much lower as visualized by total protein in-gel fluorescence (Figure 7B). This is compatible with the higher reactivity and microsecond half-life of the QM, compared to the much less reactive $a, \beta$-unsaturated ester DMF Michael acceptor. The beneficial effects of DMF have been proposed to be through activation of the Nrf2 pathway via Keap1 modification, as we have reported for $p$ NO-ASA ${ }^{44,45}$ It has also been recognized that other pathways may be involved in DMF activity, including via glyceraldehyde-3-phosphate dehydrogenase, the hydroxycarboxylic acid receptor 2, and tubulin. ${ }^{46-48}$ DMF has also been reported to increase histone acetylation by altering HDAC expression levels. ${ }^{49}$ Inhibition of the NF- $\kappa$ B pathway by covalent modification of IKK $\beta$ and p65 must also be added to this list.

\section{SUMMARY}

We have extended the mechanistic understanding of the biological activity of $p$ NO-ASA from activation of Nrf2 via QM modification of Keap1 to inhibition of the NF- $\kappa$ B pathway by QM modification of multiple proteins directly or indirectly controlling the cellular regulation of NF- $\kappa \mathrm{B} .{ }^{23}$ Inhibition of $\beta$-catenin signaling by NO-ASA and of $\beta$-catenin's ability to regulate NF- $x$ B binding to DNA has previously been reported in human colon cancer cells. ${ }^{50,51}$ Mechanisms involving the covalent modification of Cys residues of p65 leading to decreased DNA/NF- $\kappa$ B binding have also been proposed. ${ }^{52,53} \mathrm{NF}-\boldsymbol{} \mathrm{B}$ and IKK pathways often integrate their activities with other cell-signaling networks. ${ }^{54}$ Regulation of $\mathrm{NF}-\boldsymbol{\kappa B}$ activation by the AKT signaling pathway and the involvement of cytosolic Hsp60 in the NF- $x$ B-dependent survival of cancer cells via IKK regulation are two such examples. 55,56 Over 300 proteins were identified as covalently modified in colon cancer cells by $p$ NOASA and $p \mathrm{Br}-\mathrm{ASA}$. This represents a sampling of the quinonome: proteins susceptible to modification by the simple QM Michael acceptor released by ASA hybrid prodrugs. Pulldown and competition experiments showed that the proteins that constitute the quinonome were incompletely modified. It is therefore likely that biological activity results from partial modification of multiple proteins associated with pathways, such as NF- $\kappa \mathrm{B}$, and networks, such as response to oxidative stress, and protein folding (Figures 4 and 5).

We recently reported that a QM-donor ASA-DMF hybrid drug (Scheme 1) is cytotoxic toward breast cancer cells expressing cancer stem cell markers, an observation in accord with reports on the Michael acceptor natural products parthenolide and piperlongumine. ${ }^{22,57}$ As we have emphasized previously, depletion of cellular glutathione is a key contributor to biological activity. ${ }^{10,14,16}$ Under these conditions, oxidation of protein thiols in addition to direct alkylation will likely increase the extent of protein modification and therefore amplify the perturbation of protein networks. The challenge in these studies on therapeutic electrophiles will be to define the differences in cellular targets that might bias toward toxicity. 


\section{Supplementary Material}

Refer to Web version on PubMed Central for supplementary material.

\section{Acknowledgments}

Funding

This work was supported by National Institutes of Health Grant CA 102590.

\section{ABBREVIATIONS}

$\begin{array}{ll}\text { ASA } & \text { aspirin (acetylsalicylic acid) } \\ \text { pX-ASA } & \text { quinone-donating aspirins } \\ \text { CDDO-ME } & \text { bardoxolone methyl } \\ \text { CSC } & \text { cancer stem cells } \\ \text { DAPI } & 4^{\prime} \text {,6-diamidino-2-phenyl-indole } \\ \text { DMF } & \text { dimethyl fumarate } \\ \text { GO } & \text { gene ontology } \\ \text { HSE } & \text { heat shock element } \\ \text { MS } & \text { multiple sclerosis } \\ \text { NEM } & \text { N-ethylmaleimide } \\ \text { NSAIDs } & \text { non-steroidal anti-inflammatory drugs } \\ \text { NO-NSAIDs NO-donating NSAIDs } \\ \text { N3QM } & \text { azido containing quinone methide } \\ \text { PLE } & \text { porcine liver esterase } \\ \text { TNBC } & \text { quinone methide } \\ \text { triple negative breast cancer }\end{array}$

\section{References}

1. Singh J, Petter RC, Baillie TA, Whitty A. The resurgence of covalent drugs. Nat. Rev. Drug Discovery. 2011; 10:307-317. [PubMed: 21455239]

2. Evans DC, Watt AP, Nicoll-Griffith DA, Baillie TA. Drug-protein adducts: an industry perspective on minimizing the potential for drug bioactivation in drug discovery and development. Chem. Res. Toxicol. 2004; 17:3-16. [PubMed: 14727914]

3. Seidel P, Merfort I, Hughes JM, Oliver BG, Tamm M, Roth M. Dimethylfumarate inhibits NF\{kappa\}B function at multiple levels to limit airway smooth muscle cell cytokine secretion. Am. J. Physiol.: Lung Cell. Mol. Physiol. 2009; 297:L326-339. [PubMed: 19465513] 
4. Wilms H, Sievers J, Rickert U, Rostami-Yazdi M, Mrowietz U, Lucius R. Dimethylfumarate inhibits microglial and astrocytic inflammation by suppressing the synthesis of nitric oxide, IL-1beta, TNFalpha and IL-6 in an in-vitro model of brain inflammation. J. Neuroinflammation. 2010; 7:30. [PubMed: 20482831]

5. Peng H, Guerau-de-Arellano M, Mehta VB, Yang Y, Huss DJ, Papenfuss TL, Lovett-Racke AE, Racke MK. Dimethyl fumarate inhibits dendritic cell maturation via nuclear factor kappaB (NFkappaB) and extracellular signal-regulated kinase 1 and 2 (ERK1/2) and mitogen stress-activated kinase 1 (MSK1) signaling. J. Biol. Chem. 2012; 287:28017-28026. [PubMed: 22733812]

6. Kastrati I, Siklos MA, Calderon-Gierszal EL, El-Shennawy L, Georgieva G, Thayer EN, Thatcher GR, Frasor J. Dimethyl Fumarate Inhibits the Nuclear Factor kappaB Pathway in Breast Cancer Cells by Covalent Modification of p65. J. Biol. Chem. 2016; 291:3639-3647. [PubMed: 26683377]

7. Slocum SL, Kensler TW. Nrf2: control of sensitivity to carcinogens. Arch. Toxicol. 2011; 85:273284. [PubMed: 21369766]

8. Cuzick J, Otto F, Baron JA, Brown PH, Burn J, Greenwald P, Jankowski J, La Vecchia C, Meyskens F, Senn HJ, Thun M. Aspirin and non-steroidal anti-inflammatory drugs for cancer prevention: an international consensus statement. Lancet Oncol. 2009; 10:501-507. [PubMed: 19410194]

9. Thiagarajan P, Jankowski JA. Aspirin and NSAIDs; benefits and harms for the gut. Best Pract. Res., Clin. Gastroenterol. 2012; 26:197-206. [PubMed: 22542157]

10. Dunlap T, Abdul-Hay SO, Chandrasena RE, Hagos GK, Sinha V, Wang Z, Wang H, Thatcher GRJ. Nitrates and NO-NSAIDs in cancer chemoprevention and therapy: in vitro evidence querying the NO donor functionality. Nitric Oxide. 2008; 19:115-124. [PubMed: 18485921]

11. Bolla M, Almirante N, Benedini F. Therapeutic potential of nitrate esters of commonly used drugs. Curr. Top. Med. Chem. 2005; 5:707-720. [PubMed: 16101430]

12. Bratasz A, Weir NM, Parinandi NL, Zweier JL, Sridhar R, Ignarro LJ, Kuppusamy P. Reversal to cisplatin sensitivity in recurrent human ovarian cancer cells by NCX-4016, a nitro derivative of aspirin. Proc. Natl. Acad. Sci. U. S. A. 2006; 103:3914-3919. [PubMed: 16497833]

13. Bratasz A, Selvendiran K, Wasowicz T, Bobko A, Khramtsov VV, Ignarro LJ, Kuppusamy P. NCX-4040, a nitric oxide-releasing aspirin, sensitizes drug-resistant human ovarian xenograft tumors to cisplatin by depletion of cellular thiols. J. Transl. Med. 2008; 6:9. [PubMed: 18302761]

14. Dunlap T, Chandrasena RE, Wang Z, Sinha V, Thatcher GRJ. Quinone formation as a chemoprevention strategy for hybrid drugs: balancing cytotoxicity and cytoprotection. Chem. Res. Toxicol. 2007; 20:1903-1912. [PubMed: 17975886]

15. Hulsman N, Medema JP, Bos C, Jongejan A, Leurs R, Smit MJ, de Esch IJ, Richel D, Wijtmans M. Chemical insights in the concept of hybrid drugs: the antitumor effect of nitric oxide-donating aspirin involves a quinone methide but not nitric oxide nor aspirin. J. Med. Chem. 2007; 50:24242431. [PubMed: 17441704]

16. Dunlap T, Piyankarage SC, Wijewickrama GT, Abdul-Hay S, Vanni M, Litosh V, Luo J, Thatcher GR. Quinone-induced activation of Keap1/Nrf2 signaling by aspirin prodrugs masquerading as nitric oxide. Chem. Res. Toxicol. 2012; 25:2725-2736. [PubMed: 23035985]

17. Huang L, Mackenzie GG, Sun Y, Ouyang N, Xie G, Vrankova K, Komninou D, Rigas B. Chemotherapeutic properties of phospho-nonsteroidal anti-inflammatory drugs, a new class of anticancer compounds. Cancer Res. 2011; 71:7617-7627. [PubMed: 22025561]

18. Huang L, Wong CC, Mackenzie GG, Sun Y, Cheng KW, Vrankova K, Alston N, Ouyang N, Rigas B. Phospho-aspirin (MDC-22) inhibits breast cancer in preclinical animal models: an effect mediated by EGFR inhibition, p53 acetylation and oxidative stress. BMC Cancer. 2014; 14:141. [PubMed: 24575839]

19. Zhao W, Mackenzie G, Murray O, Zhang Z, Rigas B. Phosphoaspirin (MDC-43), a novel benzyl ester of aspirin, inhibits the growth of human cancer cell lines more potently than aspirin: A redoxdependent effect. Carcinogenesis. 2009; 30:512-519. [PubMed: 19136474]

20. Nath N, Chattopadhyay M, Rodes DB, Nazarenko A, Kodela R, Kashfi K. Nitric Oxide-Releasing Aspirin Suppresses NF-kappaB Signaling in Estrogen Receptor Negative Breast Cancer Cells in Vitro and in Vivo. Molecules. 2015; 20:12481-12499. [PubMed: 26184135]

21. Fionda C, Abruzzese MP, Zingoni A, Soriani A, Ricci B, Molfetta R, Paolini R, Santoni A, Cippitelli M. Nitric oxide donors increase PVR/CD155 DNAM-1 ligand expression in multiple 
myeloma cells: role of DNA damage response activation. BMC Cancer. 2015; 15:17. [PubMed: 25609078]

22. Kastrati I, Litosh VA, Zhao S, Alvarez M, Thatcher GR, Frasor J. A novel aspirin prodrug inhibits NFkappaB activity and breast cancer stem cell properties. BMC Cancer. 2015; 15:845. [PubMed: 26530254]

23. Dunlap T, Piyankarage SC, Wijewickrama GT, Abdul-Hay S, Vanni M, Litosh V, Luo J, Thatcher GR. Quinone-Induced Activation of Keap1/Nrf2 Signaling by Aspirin Prodrugs Masquerading as Nitric Oxide. Chem. Res. Toxicol. 2012; 25:2725-2736. [PubMed: 23035985]

24. Hagos GK, Carroll RE, Kouznetsova T, Li Q, Toader V, Fernandez PA, Swanson SM, Thatcher GRJ. Colon cancer chemoprevention by a novel NO chimera that shows anti-inflammatory and antiproliferative activity in vitro and in vivo. Mol. Cancer Ther. 2007; 6:2230-2239. [PubMed: 17699720]

25. Gotz MG, James KE, Hansell E, Dvorak J, Seshaadri A, Sojka D, Kopacek P, McKerrow JH, Caffrey CR, Powers JC. Aza-peptidyl Michael acceptors. A new class of potent and selective inhibitors of asparaginyl endopeptidases (legumains) from evolutionarily diverse pathogens. J. Med. Chem. 2008; 51:2816-2832. [PubMed: 18416543]

26. Keller A, Nesvizhskii AI, Kolker E, Aebersold R. Empirical statistical model to estimate the accuracy of peptide identifications made by MS/MS and database search. Anal. Chem. 2002; 74:5383-5392. [PubMed: 12403597]

27. Nesvizhskii AI, Keller A, Kolker E, Aebersold R. A statistical model for identifying proteins by tandem mass spectrometry. Anal. Chem. 2003; 75:4646-4658. [PubMed: 14632076]

28. Zhi-Liang H, Bao J, Reecy J. CateGOrizer: a web-based program to batch analyze gene ontology classification categories. Online Journal of Bioinformatics. 2008; 9:108-112.

29. Von Mering C, Jensen LJ, Snel B, Hooper SD, Krupp M, Foglierini M, Jouffre N, Huynen MA, Bork P. STRING: known and predicted protein-protein associations, integrated and transferred across organisms. Nucleic Acids Res. 2004; 33:D433-D437.

30. Franceschini A, Szklarczyk D, Frankild S, Kuhn M, Simonovic M, Roth A, Lin J, Minguez P, Bork P, von Mering C. STRING v9. 1: protein-protein interaction networks, with increased coverage and integration. Nucleic Acids Res. 2013; 41:D808-D815. [PubMed: 23203871]

31. Pierce JW, Schoenleber R, Jesmok G, Best J, Moore SA, Collins T, Gerritsen ME. Novel inhibitors of cytokine-induced $\mathrm{I} \kappa \mathrm{B} a$ phosphorylation and endothelial cell adhesion molecule expression show anti-inflammatory effects in vivo. J. Biol. Chem. 1997; 272:21096-21103. [PubMed: 9261113]

32. Zandi E, Rothwarf DM, Delhase M, Hayakawa M, Karin M. The I $x$ B kinase complex (IKK) contains two kinase subunits, IKK $a$ and IKK $\beta$, necessary for I $\kappa$ B phosphorylation and NF- $\kappa$ B activation. Cell. 1997; 91:243-252. [PubMed: 9346241]

33. Mercurio F, Zhu H, Murray BW, Shevchenko A, Bennett BL, Wu LJ, Young DB, Barbosa M, Mann M, Manning A. IKK-1 and IKK-2: cytokine-activated I $x$ B kinases essential for NF- $\kappa$ B activation. Science. 1997; 278:860-866. [PubMed: 9346484]

34. Kwok BH, Koh B, Ndubuisi MI, Elofsson M, Crews CM. The anti-inflammatory natural product parthenolide from the medicinal herb Feverfew directly binds to and inhibits $\mathrm{I} k \mathrm{~B}$ kinase. Chem. Biol. 2001; 8:759-766. [PubMed: 11514225]

35. Jeon K-I, Byun M-S, Jue D-M. Gold compound auranofin inhibits IkappaB kinase (IKK) by modifying Cys-179 of IKKbeta subunit. Exp. Mol. Med. 2003; 35:61-66. [PubMed: 12754408]

36. Surh Y-J, Na H-K. NF-kappaB and Nrf2 as prime molecular targets for chemoprevention and cytoprotection with anti-inflammatory and antioxidant phytochemicals. Genes Nutr. 2008; 2:313317. [PubMed: 18850223]

37. Meldal M, Tornøe CW. Cu-catalyzed azide-alkyne cycloaddition. Chem. Rev. 2008; 108:29523015. [PubMed: 18698735]

38. Arya R, Mallik M, Lakhotia SC. Heat shock genes-integrating cell survival and death. J. Biosci. 2007; 32:595-610. [PubMed: 17536179]

39. Garrido C, Gurbuxani S, Ravagnan L, Kroemer G. Heat shock proteins: endogenous modulators of apoptotic cell death. Biochem. Biophys. Res. Commun. 2001; 286:433-442. [PubMed: 11511077] 
40. Holzbeierlein JM, Windsperger A, Vielhauer G. Hsp90: a drug target? Curr. Oncol. Rep. 2010; 12:95-101. [PubMed: 20425593]

41. Salminen A, Paimela T, Suuronen T, Kaarniranta K. Innate immunity meets with cellular stress at the IKK complex: regulation of the IKK complex by HSP70 and HSP90. Immunol. Lett. 2008; 117:9-15. [PubMed: 18282612]

42. Liby K, Risingsong R, Royce DB, Williams CR, Ma T, Yore MM, Sporn MB. Triterpenoids CDDO-methyl ester or CDDO-ethyl amide and rexinoids LG100268 or NRX194204 for prevention and treatment of lung cancer in mice. Cancer Prev. Res. 2009; 2:1050-1058.

43. To C, Ringelberg CS, Royce DB, Williams CR, Risingsong R, Sporn MB, Liby KT. Dimethyl fumarate and the oleanane triterpenoids, CDDO-imidazolide and CDDO-methyl ester, both activate the Nrf2 pathway but have opposite effects in the A/J model of lung carcinogenesis. Carcinogenesis. 2015; 36:769-781. [PubMed: 25939751]

44. Linker RA, Lee D-HH, Ryan S, van Dam AM, Conrad R, Bista P, Zeng W, Hronowsky X, Buko A, Chollate S, Ellrichmann G, Brück W, Dawson K, Goelz S, Wiese S, Scannevin RH, Lukashev M, Gold R. Fumaric acid esters exert neuroprotective effects in neuroinflammation via activation of the Nrf2 antioxidant pathway. Brain. 2011; 134:678-692. [PubMed: 21354971]

45. Scannevin RH, Chollate S, Jung MY, Shackett M, Patel H, Bista P, Zeng W, Ryan S, Yamamoto M, Lukashev M, Rhodes KJ. Fumarates promote cytoprotection of central nervous system cells against oxidative stress via the nuclear factor (erythroid-derived 2)-like 2 pathway. J. Pharmacol. Exp. Ther. 2012; 341:274-284. [PubMed: 22267202]

46. Blatnik M, Frizzell N, Thorpe SR, Baynes JW. Inactivation of glyceraldehyde-3-phosphate dehydrogenase by fumarate in diabetes: formation of S-(2-succinyl)cysteine, a novel chemical modification of protein and possible biomarker of mitochondrial stress. Diabetes. 2008; 57:41-49. [PubMed: 17934141]

47. Chen H, Assmann JC, Krenz A, Rahman M, Grimm M, Karsten CM, Köhl J, Offermanns S, Wettschureck N, Schwaninger M. Hydroxycarboxylic acid receptor 2 mediates dimethyl fumarate's protective effect in EAE. J. Clin. Invest. 2014; 124:2188-2192. [PubMed: 24691444]

48. Piroli GG, Manuel AM, Walla MD, Jepson MJ, Brock JW, Rajesh MP, Tanis RM, Cotham WE, Frizzell N. Identification of protein succination as a novel modification of tubulin. Biochem. J. 2014; 462:231-245. [PubMed: 24909641]

49. Kalinin S, Polak PE, Lin SX, Braun D, Guizzetti M, Zhang X, Rubinstein I, Feinstein DL. Dimethyl fumarate regulates histone deacetylase expression in astrocytes. J. Neuroimmunol. 2013; 263:13-19. [PubMed: 23916696]

50. Nath N, Kashfi K, Chen J, Rigas B. Nitric oxide-donating aspirin inhibits $\beta$-catenin/T cell factor (TCF) signaling in SW480 colon cancer cells by disrupting the nuclear $\beta$-catenin-TCF association. Proc. Natl. Acad. Sci. U. S. A. 2003; 100:12584-12589. [PubMed: 14566053]

51. Deng J, Miller SA, Wang H-Y, Xia W, Wen Y, Zhou BP, Li Y, Lin S-Y, Hung M-C. $\beta$-catenin interacts with and inhibits NF- $\boldsymbol{K}$ B in human colon and breast cancer. Cancer Cell. 2002; 2:323334. [PubMed: 12398896]

52. Cheung KL, Kong A-N. Molecular targets of dietary phenethyl isothiocyanate and sulforaphane for cancer chemoprevention. AAPS J. 2010; 12:87-97. [PubMed: 20013083]

53. Switzer CH, Cheng RY-S, Ridnour LA, Murray MC, Tazzari V, Sparatore A, Del Soldato P, Hines HB, Glynn SA, Ambs S. Dithiolethiones Inhibit NF- $\kappa$ B Activity via Covalent Modification in Human Estrogen Receptor-Negative Breast Cancer. Cancer Res. 2012; 72:2394-2404. [PubMed: 22436383]

54. Perkins ND. Integrating cell-signalling pathways with NF- $\kappa$ B and IKK function. Nat. Rev. Mol. Cell Biol. 2007; 8:49-62. [PubMed: 17183360]

55. Surh Y-J. Cancer chemoprevention with dietary phytochemicals. Nat. Rev. Cancer. 2003; 3:768780. [PubMed: 14570043]

56. Chun JN, Choi B, Lee KW, Lee DJ, Kang DH, Lee JY, Song IS, Kim HI, Lee S-H, Kim HS. Cytosolic Hsp60 Is Involved in the NF- $\kappa$ B-Dependent Survival of Cancer Cells via IKK Regulation. PLoS One. 2010; 5:e9422. [PubMed: 20351780]

57. Pei S, Minhajuddin M, Callahan KP, Balys M, Ashton JM, Neering SJ, Lagadinou ED, Corbett C, Ye H, Liesveld JL, O’Dwyer KM, Li Z, Shi L, Greninger P, Settleman J, Benes C, Hagen FK, 
Munger J, Crooks PA, Becker MW, Jordan CT. Targeting Aberrant Glutathione Metabolism to Eradicate Human Acute Myelogenous Leukemia Cells. J. Biol. Chem. 2013; 288:33542-33558. [PubMed: 24089526] 

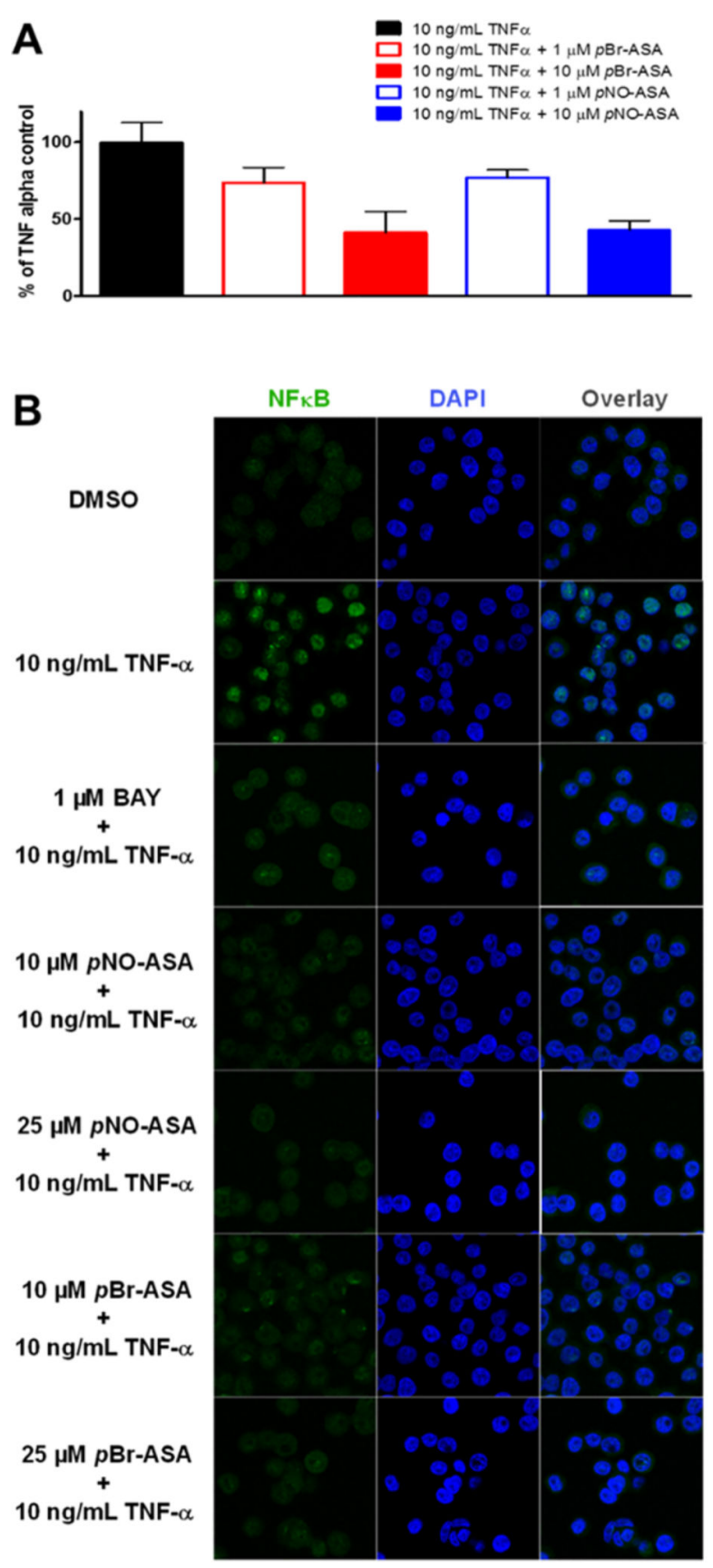

Figure 1.

Effects of $p \mathrm{X}$-ASAs on NF- $x$ B activity in HT-29 cells: (A) NF- $x$ B-luciferase activity was measured in HT-29 cells transfected with the NF- $\kappa$ B-luciferase reporter plasmid after pretreatment with DMSO, $p$ NO-ASA $(1$ and $10 \mu \mathrm{M})$, or $p \operatorname{Br}-A S A(1$ and $10 \mu \mathrm{M})$ for $2 \mathrm{~h}$ followed by treatment with TNF- $a(10 \mathrm{ng} / \mathrm{mL})$ for $4 \mathrm{~h}$. Data show means and SEMs from triplicate experiments. (B) Immunofluorescence images of fluorescein NF- $\kappa$ B staining and DAPI nuclear staining with overlapped images showing translocation of NF- $\kappa$ B from cytoplasm to nucleus. HT-29 cells were pretreated for $1 \mathrm{~h}$ with DMSO, BAY 11-7082 (1 
$\mu \mathrm{M}), p \mathrm{NO}-\mathrm{ASA}(10$ and $25 \mu \mathrm{M})$, and $p \mathrm{Br}-\mathrm{ASA}(10$ and $25 \mu \mathrm{M})$ followed by a $0.5 \mathrm{~h}$ TNF- $a$ $(10 \mathrm{ng} / \mathrm{mL})$ treatment. 


\section{Azido-pNO-ASA $(10 \mu \mathrm{M}) \quad-\quad-\quad+$ Azido-pBr-ASA $(10 \mu \mathrm{M}) \quad$ - +}

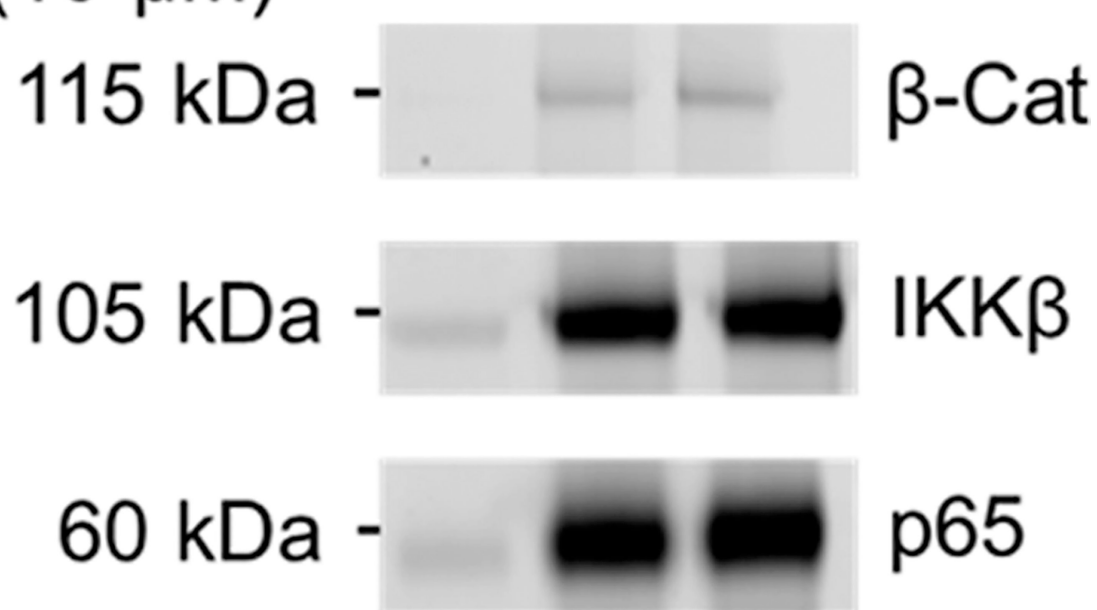

Figure 2.

In-gel fluorescence visualization of $\beta$-catenin, IKK $\beta$, and p65 modification by $\mathrm{N}_{3} \mathrm{QM}$ : recombinant $\beta$-catenin, IKK $\beta$, and p65 was treated with DMSO, azido- $p$ Br-ASA $(10 \mu \mathrm{M})$, and azido- $p$ NO-ASA $(10 \mu \mathrm{M})$ for $0.5 \mathrm{~h}$ in the presence of $30 \mu \mathrm{g} / \mathrm{mL}$ PLE. Following click chemistry and SDS-PAGE gel electrophoresis, protein modification by the $\mathrm{N}_{3} \mathrm{QM}$ was measured using in-gel fluorescence. Representative images from the in-gel fluorescence analysis of three independent experiments are shown. 

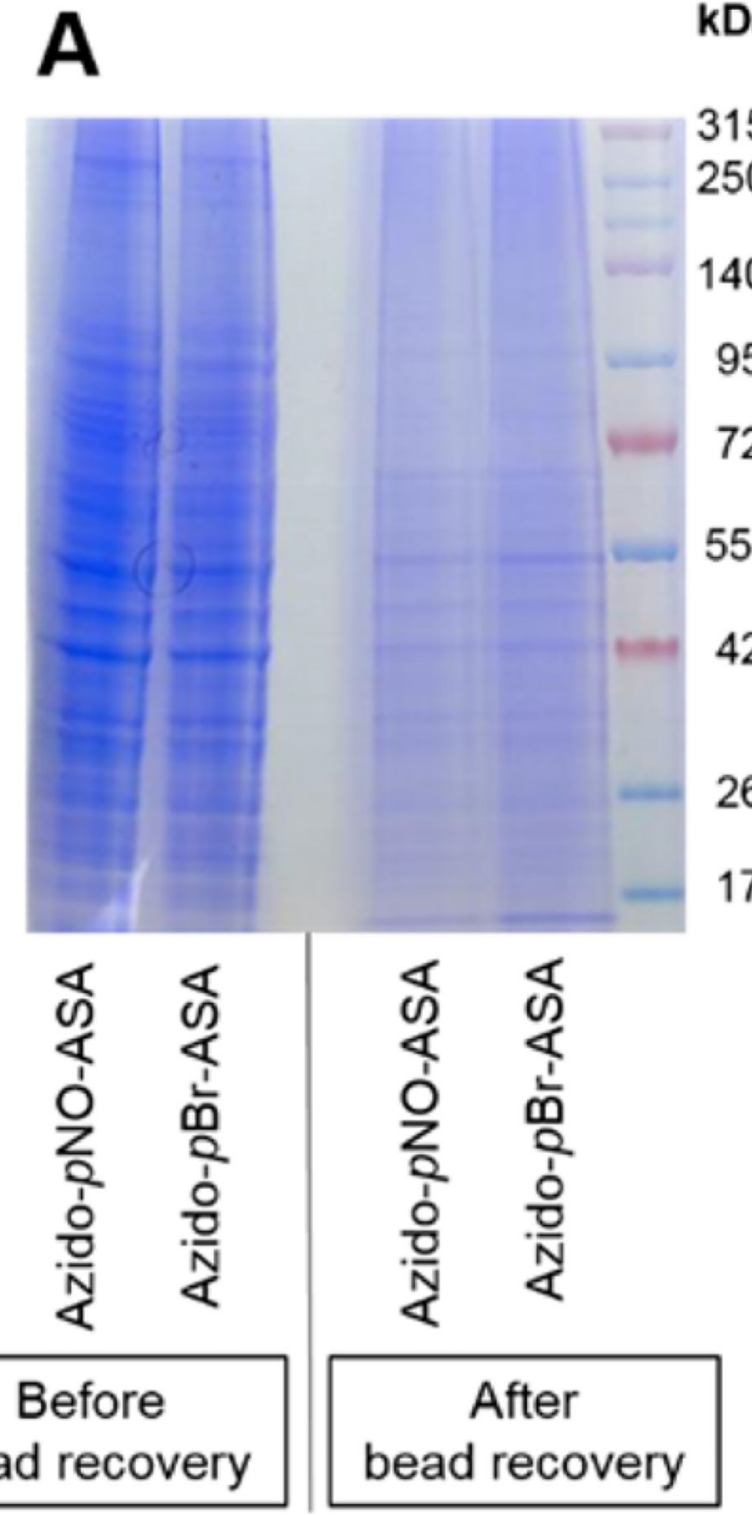

kDa

B

kDa

315

250

140

95

72

55

42

26

17

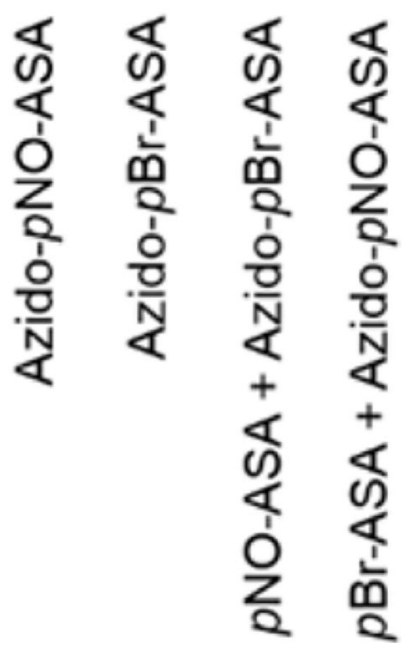

Figure 3.

Visualizing the $\mathrm{N}_{3} \mathrm{QM}$ modified proteins in HT-29 cells: (A) lysates from HT-29 cells treated with DMSO, azido- $p$ NO-ASA $(10 \mu \mathrm{M})$, azido- $p \operatorname{Br}-\mathrm{ASA}(10 \mu \mathrm{M})$, clicked to biotin, and applied on to the streptavidin-coated magnetic beads to separate the QM-modified proteins from the unmodified. All fractions were run on SDS-PAGE gel electrophoresis and stained with Coomassie brilliant blue. (B) Lysates from HT-29 cells treated with DMSO, azido- $p$ NO-ASA $(10 \mu \mathrm{M})$, and azido- $p$ Br-ASA $(10 \mu \mathrm{M})$, with or without $p$ NO-ASA $(10 \mu \mathrm{M})$ or $p \mathrm{Br}-\mathrm{ASA}(10 \mu \mathrm{M})$ pretreatments, clicked to biotin, and subjected to Western blotting with the use of antibiotin-HRP for visual characterization of the modified proteins.

Representative Western blotting analysis from three independent experiments are shown. 


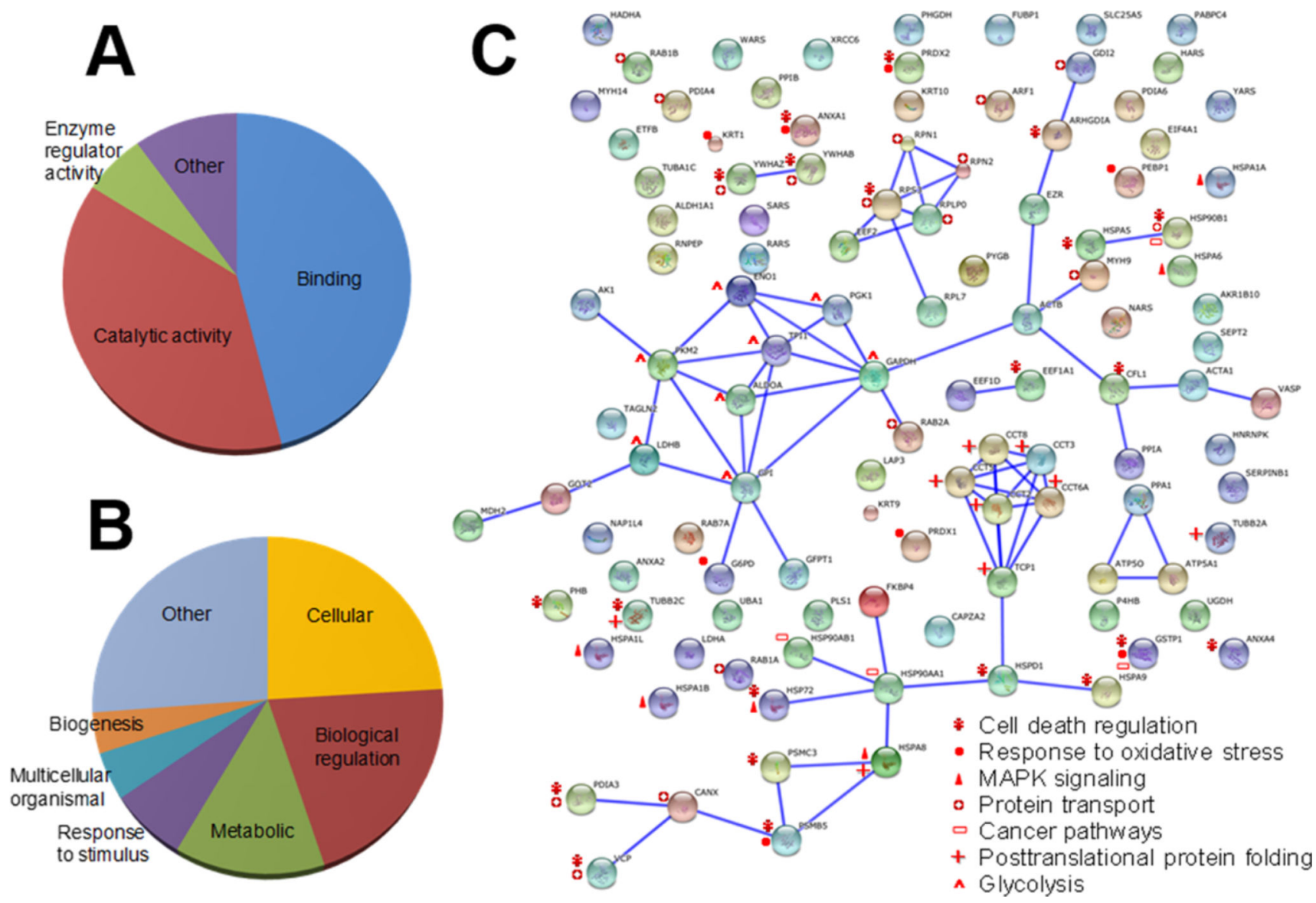

Figure 4.

Bioinformatic analysis of the putative QM target proteins. GOslim, gene ontology analysis of the target proteins was performed using the CateGOrizer program. The identified QMmodified proteins were annotated by their (A) molecular function and (B) biological process for initial characterization. (C) Interconnectivities of the identified QM-modified proteins were established using the STRING (Search Tool for the Retrieval of Interacting Genes) database. Each marble represents an identified QM-modified protein with its important physiological roles and associated pathways. Three highly interconnected protein networks are also shown. 
Proteolysis: Putative ubiquitin pathway Cell cycle: Role of 14-3-3 proteins in cell cycle regulation Immune response: HSP60 and HSP70/ TLR signaling pathway Apoptosis and survival:ER stress response pathway Cell cycle:Role of Nekin cell cycle regulation Cytoskeleton remodeling: Reverse signaling by ephrin B

Regulation of degradation of deltaf508 CFTR in CF Development:Glucocor ticoid receptor signaling Mechanisms of CFTR activation by S-nitrosoglutathione Cytoskeleton remodeling: PKA role in cytoskeleton reorganisation Development: MAG-dependent inhibition of neurite outgrowth Cell adhesion: Role of tetraspanins in integrin-mediated adhesion Aminoacyl: tRNA biosynthesis in cytoplasm Transport: Macropinocytosis Cell adhesion: Gap junctions Transcription: Role of Akt in hypoxia induced HIF1 activation Proteolysis: Role of Parkin in the Ubiquitin-Proteasomal Pathway CFTR folding and maturation Immune response: Antigen presentation by MHC Glycolysis and gluconeogenesis LRRKZ in neurons in Parkinson's disease

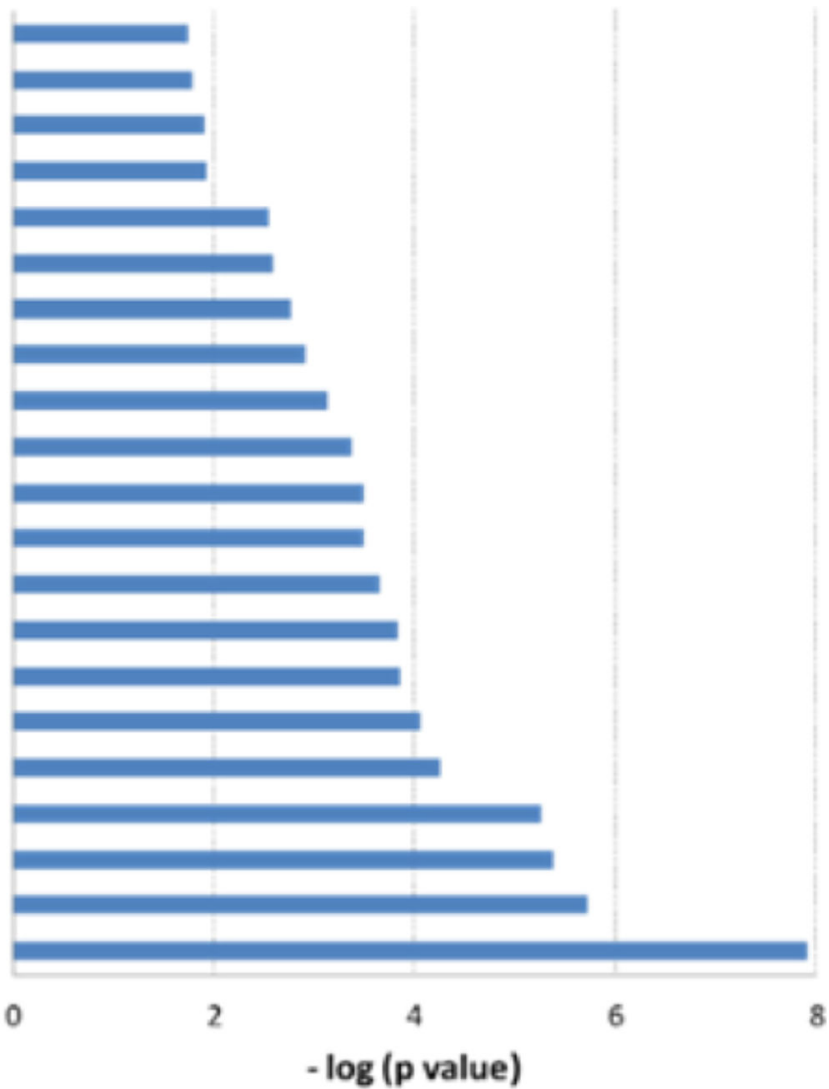

Figure 5.

Most significant canonical signaling pathways associated with the 220 QM-modified protein targets according to MetaCore software analysis. 


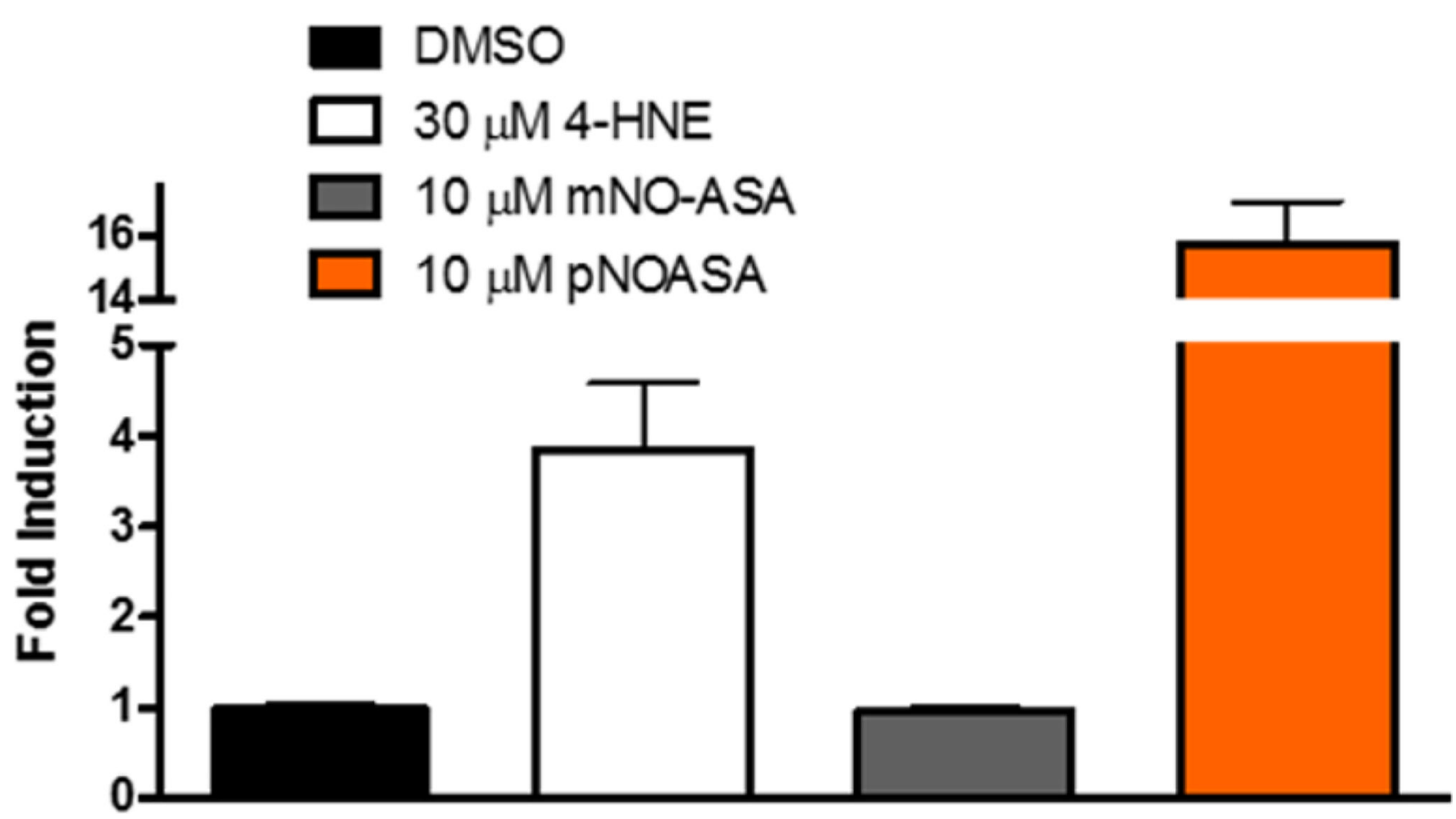

Figure 6.

Effect of $m / p N O-A S A$ on HSE in HT-29 cells. HSE-luciferase activity was measured in HT-29 cells transfected with the HSE-luciferase reporter plasmid following treatment with DMSO, 4-HNE $(30 \mu \mathrm{M}), m N O-A S A(10 \mu \mathrm{M})$, and $p$ NO-ASA $(10 \mu \mathrm{M})$ for $24 \mathrm{~h}$. Data show the means and SEMs from triplicate experiments. 

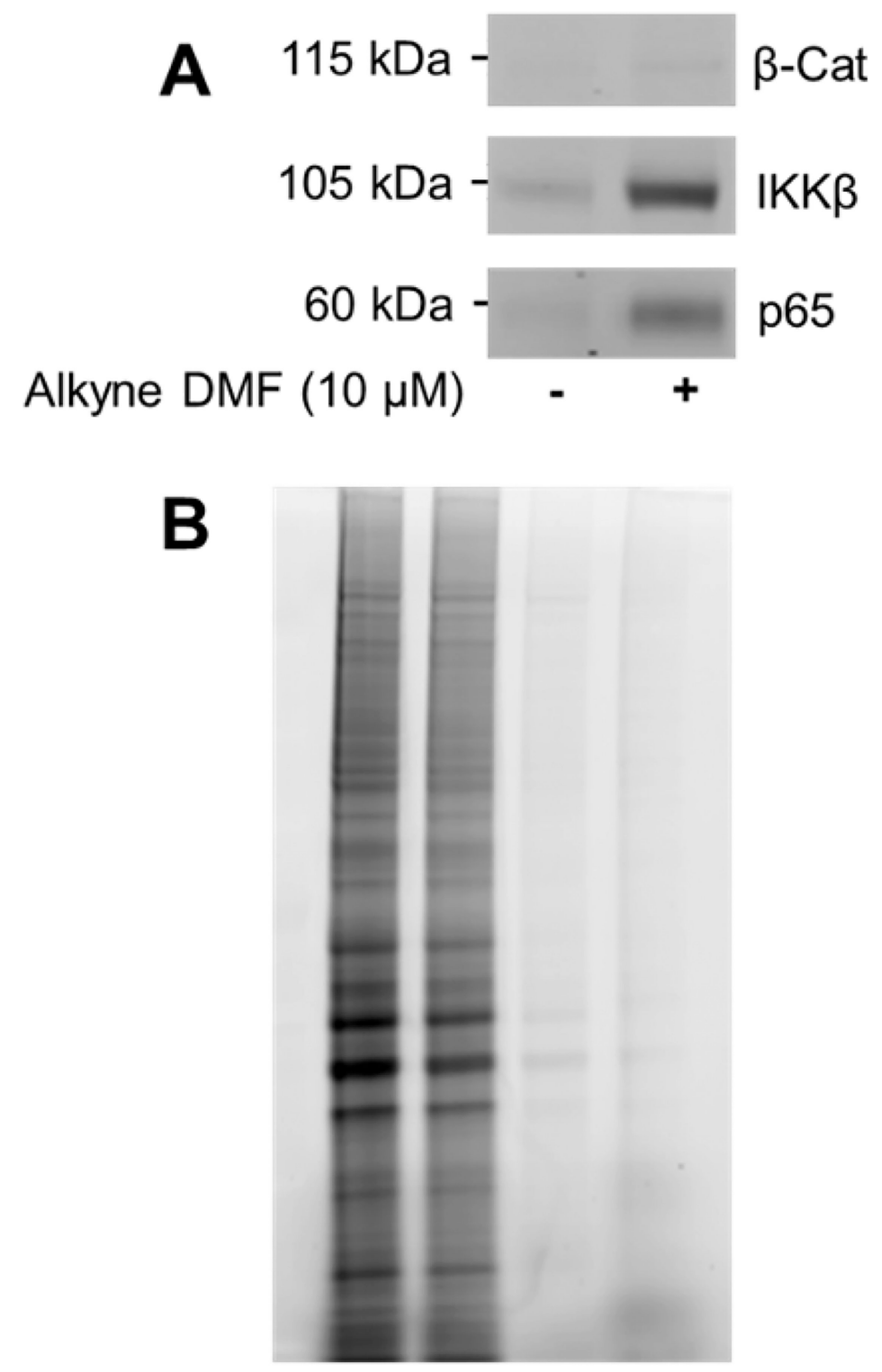
Alkyne-DMF $(10 \mu \mathrm{M})$

Figure 7.

Comparing levels of protein modification by DMF and $\mathrm{N}_{3} \mathrm{QM}$ : (A) recombinant $\beta$-catenin, IKK $\beta$, and p65 was treated with alkyne-DMF $(10 \mu \mathrm{M})$ for $0.5 \mathrm{~h}$. (B) PC12 cell lysates were treated with DMSO, alkyne-DMF $(10 \mu \mathrm{M})$, azido- $p$ Br-ASA $(10 \mu \mathrm{M})$, and azido- $p$ NO-ASA $(10 \mu \mathrm{M})$ for $0.5 \mathrm{~h}$ in the presence of $30 \mu \mathrm{g} / \mathrm{mL}$ porcine liver esterase for the $p \mathrm{X}$-ASA samples. Following click chemistry and SDS-PAGE gel electrophoresis, protein modification was measured using in-gel fluorescence. Repersentative images from the in-gel fluorescence analysis of three independent experiments are shown. 


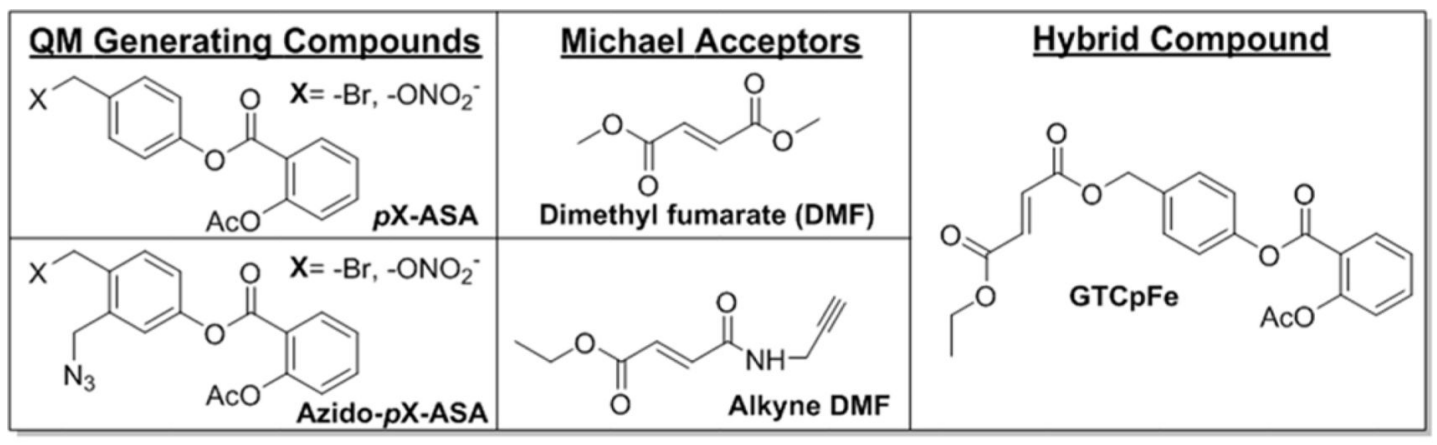

Quinone Methide Dimethylfumarate<smiles>[X]Cc1ccc(OC(=O)c2ccccc2OC(C)=O)cc1CN</smiles>

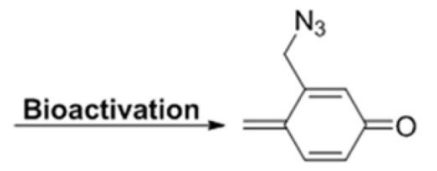<smiles>C#CCNC(=O)/C=C/C(=O)OCC</smiles>
$\mathrm{X}=\mathrm{Br}, \mathrm{ONO}_{2}^{-}$
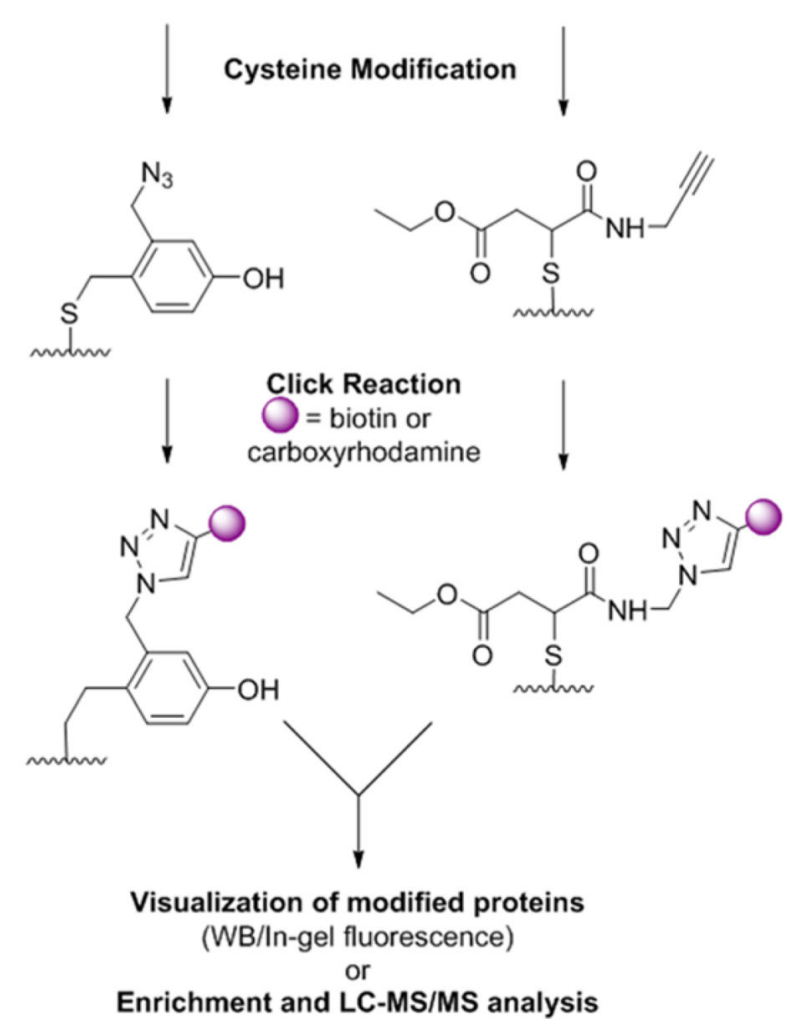

Scheme 1.

Methodology Employed to Identify Proteins Convalently Modified by the Electrophilic Quinone Methide Released upon Bioactivation of the Azido-pX-ASA Probes or the Simple Michael Acceptor in Alkyne-DMF 


\section{Table 1}

Analysis of QM- and NEM-Modified Cys-Containing Peptides of IKK- $\beta^{a}$ Reacted with $p$ NO-ASA

\begin{tabular}{|c|c|c|}
\hline \multirow[b]{2}{*}{ peptide } & \multicolumn{2}{|c|}{$\begin{array}{c}\% \\
\text { modification }\end{array}$} \\
\hline & QM & NEM \\
\hline MSWSPSLTTQTC $_{12}$ GAWEMKER & 94 & 6 \\
\hline WHNQETGEQIAIKQC $_{46} \mathrm{R}$ & 74 & 26 \\
\hline NRERWC $_{59}$ LEIQIMR & 27 & 73 \\
\hline GTDPTYGPNGC $_{299} \mathrm{FK}$ & 69 & 31 \\
\hline IQQDTGIPEEDQELLQEAGLALIPDKPATQC $_{370}$ ISDGK & 93 & 7 \\
\hline ITYETQISPRPQPESVSC $_{412} I_{L Q E P K}$ & 95 & 5 \\
\hline $\mathrm{KVWGQVWHSIQTLKEDC}_{444} \mathrm{NR}$ & 58 & 42 \\
\hline EMEQAVELC $_{524} \mathrm{GR}$ & 18 & 82 \\
\hline
\end{tabular}

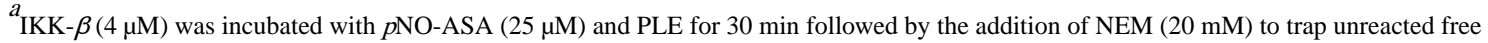
thiols. 